\title{
Understanding Why Human Resource Function is Lagging behind in Information Technology Adoption
}

\author{
Robert Kinanga \\ Jomo Kenyatta University of Agriculture and Technology, Nairobi, Kenya
}

\begin{abstract}
In the current Information Age the success of any department within an organization world over is centered on the extent to which it is able to adopt and adapt to new changes in Information technology (IT). Human Resource Function is one of the key departments but has been lagging behind in adoption of this Technology. This study aimed at understanding the reason for this sorry state of affair by investigating the extent to which IT policy Framework, IT Implementation, IT Literacy and IT Infrastructure determine the adoption of IT in the Human Resource function in Kenyan public universities. The study used inferential survey research design where both qualitative and quantitative techniques were employed to analyze data. Spearman's rho was used to test the null hypotheses there is no significant correlation between independent variables and dependent variable. In addition the researcher used the Ordinal Logistic Regression Analysis to model the relationship between Human Resource Function and the predictor variables. The main findings of the study are that there is a positive significant relationship between the independent variables and dependent variable. Basing on the study it was suggested that for proper adoption of IT in the HR Function within the Kenyan public universities it is important to ensure there is an IT policy that employees are aware of. Second, there is need to have a well planned and organized IT implementation procedure. Third, Management should promote and organize IT literacy skills training and finally, provide adequate IT infrastructure to facilitate IT adoption.
\end{abstract}

Keywords: IT Adoption, Kenyan Public Universities, Human Resource Function.

\section{Introduction}

Human resource function is one of the key departments in any organization that is involved in HRM activities such as Human Resource planning, Recruitment and selection, Training and Development, Performance Management and Industrial Relations among others. Studies undertaken in developed countries indicate that HR department has not been left behind in taking note of the current trends in technology. Scholars have detected trend towards Information Technology adoption in Human Resource function and argue that though investments in IT are in top gear information tools applied to employees pale in comparison with those used in other functional areas like Marketing, Finance, etc. (Dunivan, 1991; Boudreau, 1995). This trend of lagging behind was not only noticed in the 1990 's but also as recent as beyond 2000 but according to Grobler and Warnich (2006) perhaps later than many other business functions, technology has recently come into HRM in a major way.

Copyright (C) 2012 Robert Kinanga. This is an open access article distributed under the Creative Commons Attribution License unported 3.0, which permits unrestricted use, distribution, and reproduction in any medium, provided that original work is properly cited. Contact author: Robert Kinanga E-mail: rongeta@yahoo.com 
Regardless of this late adoption of Information Technology it has come to transform the way the Human Resource Department plays it roles in a positive way. Scott and Bohlandern (2007) noted that information technology, of course, changed the face of HRM in the United States and abroad. Perhaps the most central use of technology in HRM is an organization's Human Resources Information System (HRIS). The most obvious impact has been operational, that is, automating routine activities, alleviating administrative burdens, reducing costs, and improving productivity internal to the HR function itself. Further, Teo, et.al 2001 notes that there has also been some evidence to suggest that HR has been a laggard in adopting IT but does not provide reasons for this. Consequently, the success of this trend towards IT adoption in HRM practices can only be guaranteed if there is proper understanding of the critical factors in adopting Information Technology.

In Kenya the achievement of an informationbased society is one of the main priorities... in order to realize national development goals and objectives for wealth and employment creation" (Poghisio, 2008). After several years of effort, Kenya promulgated a National ICT Policy in January 2006 that aims to "improve the livelihoods of Kenyans by ensuring the availability of accessible, efficient, reliable and affordable ICT services." The Kenyan ICT policy and the closely related e-government strategy, the government has a mission "to use information and communication technology to improve the livelihoods of the people of Kenya and optimize its contribution to the development of the economy by ensuring the availability of efficient ,reliable and affordable info-communication services throughout the country ( Kenya' s ICT policy,2006).

The national policy has several sections, including information technology, broadcasting, telecommunications, and postal services. However, it is the section on information technology that sets out the objectives and strategies pertaining to ICT and education. The relevant objective in this section states that government will encourage "...the use of ICT in schools, colleges, universities and other educational institutions in the country so as to improve the quality of teaching and learning. Surprisingly, in terms of adoption of information communication technology according to Siambi (2008) the vicechairman of public service commission, Kenya has come a long way from the era of using mainframe computers to the modern world of wireless and mobile technology, ICT as evident in the country's national plans and other government initiatives. In 2007, the government launched the ICT Board to oversee the development of ICT in Kenya and the National Analogue Digital Broadcasting migration plan to be finalized by 2012 (Kenya vision 2030).

To achieve Kenya vision 2030, it is indicated that as part of the on-going public sector reforms, the government has endeavored to leverage the use of information technology in order to give Kenyans services that are prompt, convenient and responsive to their demand. The development of integrated government-wide information systems has been accelerated. These include the integrated financial Management System and integrated Personnel and Payroll system, online recruitment and selection system, online exam results and pension system.

According to the article 'Knowledge creation and dissemination in African Universities with special reference to ICT' written by Teffarra ( 2004) published in African Universities in the $21^{\text {st }}$ Century book of CODESTRIA, as developments in and usage of Information and Communications Technology (ICT) in the developed world have intensified, the scope and dimension of communicating and advancing knowledge have evolved remarkably. African Universities as major consumers, brokers, and producers of the knowledge industry in the continent-bear witness to the unfolding events and developments. In the Higher 
Education sector, the adoption and use of ICT services is realized through the extent to which ICT supports and fosters innovative research learning and teaching in addition to supporting administrative processes in these institutions. According to Pfeffer (2003) ICT has a clear impact on universities in a holistic and comprehensive manner, not only on academic processes but on functions. However, according to Teferra (2004) the extent and scope of the utilization of ICT by African Universities, and how it affects research, teaching, and other scholarly activities, remain a less studied area.

Basing on Unified Theory of Acceptance and Use of Technology (UTAUT), which was a review by Venkatesh et al. (2003) of the eight most prominent models/Theories that predict behavior intentions and/or usage. The study aimed at contribution to the UTAUT theory by determining whether Information Technology Policy Framework, Implementation Procedure IT literacy and IT Infrastructure are the facilitating conditions that are necessary for IT behavioral usage.

\section{Statement of the Problem}

The level and speed to which Information Technology is being adopted and implemented at Kenyan public universities has been applauded by many scholars such as Mutula, 2001, Wanyembi, 2002, Agbonlour (2006), Farrell (2007) among many others. Specifically, Mutula (2001) notes that the clamor for and rapid rise in the application of computers in both academic and administrative departments is a clear sign of this recognition. Human resource management has become more complex due to the fast growth in specialized occupations, the need to train and promote highly skilled employees, and the growing variety of benefits programs. HRM can be classified into five main activities according to $\mathrm{Oz}$ (2009): (1) employee record management, (2) promotion and recruitment,(3) training, (4) evaluation, and (5) compensation and benefits management. The effectiveness and efficiency of HR department in Kenyan public Universities to undertake these critical activities are depended upon the adoption of IT technology. However, the adoption and implementation has been characterized by many shortcomings due to a number of limitations.

First, there are no policy frameworks, at either organizational or national level, to guide the adoption of this technology to realize its full potential benefits [DN 9 July 2001]. Within a short period of time, public universities in Kenya have had to cope with a diversity of new ICT related problems over and above their old 'normal' problems on the economic, social, governmental and political fronts. Ayoo and Otike (2002) note that the formulation of an information policy in Kenya is hampered by the lack of information skills, mainly among top policy makers, which results in making the wrong choices of ICTs. Secondly, information Technology implementation procedures appear to be disjointed and disorganized according to Wanyembi(2002) who noted that the manner in which information and communication technology was introduced in Kenyan public universities was initially piecemeal, uncoordinated, and in most cases haphazard.

Thirdly, according to Mutula (2001) the new problems, which are closely linked with the introduction of the computer technology, include low computer literacy among staff among other reasons. In agreeing with this state of affair Tilvawala et al (2009) notes that one barrier to the efficient utilization of ICT in developing countries is the relatively low level of information literacy. Finally, another challenge facing the adoption of Information Technology is securing and installing the information and communication technology (ICT) resources (Mutula, 2001). According to a World Bank Institute survey, the state of ICT infrastructure in African universities can be summed up as "too little, too expensive, and poorly managed." 
Though the above challenges, facing Information Technology adoption have been detected in other areas within public universities in Kenya such as the library department Wanyembi 2002, there lacks evidence of a study of their effect on the adoption of Information Technology in human resource function. This raises the general question whether these challenges are the determinants in successful adoption of IT for improving Human Resource Function in Kenyan Public Universities.

\section{Research Hypothesis}

$\boldsymbol{H}_{\boldsymbol{0}}$ 1: There is no significant correlation between IT Policy framework and adoption of IT for improving HR function in Kenyan public universities.

$\boldsymbol{H}_{\boldsymbol{0}}$ 2: There is no significant correlation between IT implementation procedures and adoption of IT for improving Human Resource Function in Kenyan public universities.

$\boldsymbol{H}_{\boldsymbol{0}}$ 3: There is no significant correlation between Information Technology literacy of HR employees and adoption of IT for improving HR function in Kenyan public universities.

$\boldsymbol{H}_{0}$ 4: There is no significant correlation between availability of Information Technology Infrastructure and adoption of IT for improving HR function in Kenyan public universities.

\section{Research Methodology}

The study used inferential survey research design which according to Easterby-Smith et.al, 2008 is aimed at establishing relationships between variables and concepts, whether there are prior assumptions and hypotheses regarding the nature of these relationships. The sample sizes of 123 respondents were derived from the target population of 130 in the Human Resource Department employees within the seven Kenya public universities. The researcher used the questionnaire as the main data collection instrument which was seen as most recommended tool of data collection when you are dealing with a large sample. Kumar (2005) notes, that questionnaires are less expensive since one saves time, human and financial resources and convenient.

The research instrument was justified to be used for collecting data because the Cronbach Alpha coefficient was 0.811. These correlations were considered adequate since researchers generally recommend values of $r$ $=.80$, or larger as ideal when using correlation to measure the reability of measurement (Gravetter \& Forzano, 2009).

First, Descriptive information after content analysis was converted into frequencies and percentages and presented using tables, piecharts and histograms. Second, the study aimed at establishing the associations between the independent variables and dependent variable hence the need to undertake correlation analysis. Gray (2009) notes that when as association is measured numerically, we get a correlation coefficient that gives the strength and the direction of the relationship between two variables. In addition to the strength of a relationship, we might also be interested in the direction an association such as positive or negative. Since the variables in this study are ordinal in nature spearman's rank-order correlation, often known as Spearman's rho was used to test the hypothesis.

Further, regression analysis was conducted to predict the value of relationship between the independent variables and dependent variable. In this case, since there where more than one independent variables- or predictors that is IT policy, IT implementation procedure, IT literacy and IT infrastructure on a single dependent variable, or outcome that is Improving Human Resource Function a multivariate analysis technique was used. In particular multinomial (or Polychotomous) logistic regression was used since the dependent 
variable was categorical in that it contained ordinal variables ranging from Strongly Disagree to Strongly Agree. According to Field (2009) logistic regression which is an extension of regression allows us to predict categorical outcomes based on predictor variables. If we want to predict membership of more than two categories we use multinomial logistic regression.

Specifically, Ordinal logistic regression analysis which is a statistical technique that models the relationship between a criterion or dependent variable (Y) and a set of predictor or independent variables (Xi) (for $i=1,2,3,4)$ was used. However, for the ordinal logistic regression analysis to hold, the dependent variable should be ordinal (ranked). In this study, the dependent variable (Human Resource Function) was ordinal and hence the researcher used the Ordinal Logistic Regression Analysis to model the relationship between Human Resource Function and the predictor variables. This statistical relationship is of the form:

$Y=\exp \left(\beta_{0}+\beta_{1} X_{1}+\beta_{2} X_{2}+\beta_{3} X_{3}+\beta_{4} X_{4}+\varepsilon\right)$

Where $\mathrm{X}_{1}$ is the scores of factor 1 - IT Policy

$\mathrm{X}_{2}$ is the scores of factor 2 - IT Implementation Procedure

$\mathrm{X}_{3}$ is the scores of factor 3 - IT Literacy

$\mathrm{X}_{4}$ is the scores of factor 4 - IT Infrastructure

$\varepsilon$ is the error term $\beta_{\mathrm{i}}$ are the parameters to be estimated

$\mathrm{Y}$ is the dependent variable, Human Resource Function

\section{Presentation of Findings}

\section{Demographic Characteristics of the Respondents}

The respondents for this study were a total of 118 in which $73(61.9 \%)$ were male and 45 (38.1\%) female. Majority of the respondents $42(35.6 \%)$ are between age 38-48 years, 37 (31.4\%) above 48 years, 27 (22.9\%) between 28-38 years and 12 (10.2\%) between 18-28 years which did not have any significant effect on the outcome of the study.

\section{Results on IT Adoption Independent Variables}

The respondents were asked to give their answers to five likert scale closed ended questions in a scale of 1-5 where 1- Strongly Disagree, 2-Disagree, 3- Not Sure, 4- Agree, 5Strongly Agree on the independent variables; IT policy framework, IT implementation Procedure, IT literacy and IT infrastructure.

\section{IT Policy Framework}

HR employees in the seven public universities were asked to indicate their level of agreement of statements related to IT policy framework in their respective HR departments. Table 4.2 presents findings on IT policy framework. 
Table 3.1: Information Technology Policy Framework

\begin{tabular}{|l|l|l|l|l|l|l|l|l|l|l|l|}
\hline & \multicolumn{2}{l}{ SD } & \multicolumn{2}{l|}{ D } & \multicolumn{2}{l|}{ NS } & \multicolumn{2}{l|}{ SA } \\
\cline { 2 - 13 } & Freq & $\%$ & Freq & $\%$ & Freq & $\%$ & Freq & $\%$ & Freq & $\%$ \\
\hline Existence of IT Policy & 32 & 27.1 & 30 & 25.4 & 24 & 20.3 & 18 & 15.3 & 14 & 11.9 \\
\hline Awareness of IT Policy & 25 & 21.2 & 59 & 50 & 5 & 4.2 & 20 & 16.9 & 9 & 7.6 \\
\hline adequacy of IT policy & 6 & 5.1 & 35 & 29.7 & 62 & 52.5 & 8 & 6.8 & 7 & 5.9 \\
\hline Applies to all users & 49 & 41.5 & 36 & 30.5 & 22 & 18.6 & 4 & 3.4 & 7 & 5.9 \\
\hline $\begin{array}{l}\text { IT policies sets parameters } \\
\text { for Appropriate use }\end{array}$ & 18 & 15.3 & 33 & 28 & 33 & 28 & 20 & 16.9 & 14 & 11.9 \\
\hline $\begin{array}{l}\text { Enforcement procedures in } \\
\text { case of inappropriate use }\end{array}$ & 24 & 20.3 & 41 & 34.7 & 39 & 33.1 & 14 & 11.9 & 0 & 0 \\
\hline $\begin{array}{l}\text { Indication for further } \\
\text { development of IT }\end{array}$ & 24 & 20.3 & 25 & 21.2 & 56 & 47.5 & 13 & 11 & 0 & 0 \\
\hline $\begin{array}{l}\text { Proper authorization to } \\
\text { access IT systems }\end{array}$ & 24 & 20.3 & 39 & 33.1 & 36 & 30.5 & 13 & 11 & 6 & 5.1 \\
\hline $\begin{array}{l}\text { Rules on use of personal } \\
\text { computers on the network }\end{array}$ & 24 & 20.3 & 21 & 17.8 & 51 & 43.2 & 18 & 15.3 & 4 & 3.4 \\
\hline
\end{tabular}

\section{IT Implementation Procedure}

HR employees in the seven public universities were asked to indicate their level of agreement of statements related to IT implementation procedure in their respective HR departments. Table 4.3 presents findings on IT implementation procedure.

Table 3.2 Information Technology Implementation Procedure

\begin{tabular}{|l|l|l|l|l|l|l|l|l|l|l|l|}
\hline & \multicolumn{3}{l}{ SD } & \multicolumn{1}{l}{ D } & \multicolumn{2}{l|}{ NS } & A & \multicolumn{2}{l|}{ SA } \\
\cline { 2 - 12 } & Freq & $\%$ & Freq & $\%$ & Freq & $\%$ & Freq & $\%$ & Freq & $\%$ \\
\hline $\begin{array}{l}\text { Changing from manual to IT } \\
\text { systems }\end{array}$ & 55 & 46.6 & 31 & 26.3 & 23 & 19.5 & 4 & 3.4 & 5 & 4.2 \\
\hline $\begin{array}{l}\text { Introduction of IT systems is } \\
\text { well planned and organized }\end{array}$ & 54 & 45.8 & 10 & 8.5 & 38 & 32.2 & 14 & 11.9 & 2 & 1.7 \\
\hline Top management support & 29 & 24.6 & 24 & 20.3 & 34 & 28.8 & 29 & 24.6 & 2 & 1.7 \\
\hline $\begin{array}{l}\text { Procedures in introduction of } \\
\text { IT systems }\end{array}$ & 24 & 20.3 & 19 & 16.1 & 38 & 32.2 & 27 & 22.9 & 10 & 8.5 \\
\hline $\begin{array}{l}\text { Implementation of IT is in line } \\
\text { with organizational goals }\end{array}$ & 10 & 8.5 & 46 & 39 & 26 & 22 & 34 & 28.8 & 2 & 1.7 \\
\hline $\begin{array}{l}\text { Management committing } \\
\text { organizational resources }\end{array}$ & 32 & 27.1 & 28 & 23.7 & 23 & 19.5 & 33 & 28 & 2 & 1.7 \\
\hline $\begin{array}{l}\text { Implementation of IT is an all } \\
\text { inclusive exercise }\end{array}$ & 24 & 20.3 & 45 & 38.1 & 29 & 24.6 & 18 & 15.3 & 2 & 1.7 \\
\hline $\begin{array}{l}\text { Implementation of IT has } \\
\text { measurable objectives }\end{array}$ & 18 & 15.3 & 21 & 17.8 & 51 & 43.2 & 26 & 22 & 2 & 1.7 \\
\hline $\begin{array}{l}\text { Clear timeline with } \\
\text { completion targets }\end{array}$ & 16 & 13.6 & 43 & 36.4 & 33 & 28 & 24 & 20.3 & 2 & 1.7 \\
\hline $\begin{array}{l}\text { HR employee have duty to } \\
\text { manage IT systems }\end{array}$ & 54 & 45.8 & 27 & 22.9 & 23 & 19.5 & 0 & 0 & 14 & 11.9 \\
\hline
\end{tabular}


7 Journal of Human Resources Management Research

\section{IT Literacy}

HR employees in the seven public universities were asked to indicate their level of agreement of statements related to IT literacy levels in their respective HR departments. Table 4.4 presents findings on IT literacy levels.

Table 3.3 Information Technology Literacy

\begin{tabular}{|l|l|l|l|l|l|l|l|l|l|l|l|}
\hline & \multicolumn{3}{|l}{ SD } & D & \multicolumn{2}{l|}{ NS } & A & \multicolumn{2}{l|}{ SA } \\
\cline { 2 - 12 } & Freq & $\%$ & Freq & $\%$ & Freq & $\%$ & Freq & $\%$ & Freq & $\%$ \\
\hline $\begin{array}{l}\text { HR function has organized IT } \\
\text { training }\end{array}$ & 54 & 45.8 & 43 & 36.4 & 4 & 3.4 & 15 & 12.7 & 2 & 1.7 \\
\hline $\begin{array}{l}\text { HR employees have undergone IT } \\
\text { training without assistance }\end{array}$ & 32 & 27.1 & 8 & 6.8 & 0 & 0 & 40 & 33.9 & 38 & 32.2 \\
\hline $\begin{array}{l}\text { HR function has circulated IT } \\
\text { manuals }\end{array}$ & 74 & 62.7 & 0 & 0 & 25 & 21.2 & 15 & 12.7 & 4 & 3.4 \\
\hline Level of IT literacy is sufficient & 8 & 6.8 & 6 & 5.1 & 32 & 27.1 & 70 & 59.3 & 2 & 1.7 \\
\hline $\begin{array}{l}\text { confidence in carrying out HR } \\
\text { activities using IT }\end{array}$ & 10 & 8.5 & 20 & 16.9 & 10 & 8.5 & 44 & 37.3 & 34 & 28.8 \\
\hline $\begin{array}{l}\text { Confidence in selecting appropriate } \\
\text { IT technology }\end{array}$ & 10 & 8.5 & 6 & 5.1 & 34 & 28.8 & 50 & 42.4 & 18 & 15.3 \\
\hline $\begin{array}{l}\text { Confidence in necessary skills to use } \\
\text { IT in HR }\end{array}$ & 8 & 6.8 & 18 & 15.3 & 10 & 8.5 & 64 & 54.2 & 18 & 15.3 \\
\hline confidence in use of IT skills in HR & 6 & 5.1 & 12 & 10.2 & 20 & 16.9 & 58 & 49.2 & 22 & 18.6 \\
\hline $\begin{array}{l}\text { Confidence in helping other } \\
\text { employees to solve IT problems }\end{array}$ & 14 & 11.9 & 18 & 15.3 & 16 & 13.6 & 38 & 32.2 & 32 & 27.1 \\
\hline
\end{tabular}

\section{IT Infrastructure}

HR employees in the seven public universities were asked to indicate their level of agreement of statements related to IT Infrastructure in their respective HR departments. Table 4.4 presents findings on IT Infrastructure.

Table 3.4: Information Technology Infrastructure

\begin{tabular}{|l|l|l|l|l|l|l|l|l|l|l|l|}
\hline & \multicolumn{2}{l}{ SD } & D & \multicolumn{2}{l|}{ NS } & \multicolumn{2}{l|}{ A } \\
\cline { 2 - 11 } & Freq & $\%$ & Freq & $\%$ & Freq & $\%$ & Freq & $\%$ & Freq & $\%$ \\
\hline $\begin{array}{l}\text { Sufficiency of IT } \\
\text { infrastructure }\end{array}$ & 47 & 39.8 & 48 & 40.7 & 18 & 15.3 & 4 & 3.4 & 1 & 0.8 \\
\hline $\begin{array}{l}\text { Availability of IT } \\
\text { telecommunication } \\
\text { systems }\end{array}$ & 59 & 50 & 30 & 25.4 & 16 & 13.6 & 6 & 5.1 & 7 & 5.9 \\
\hline $\begin{array}{l}\text { Availability of IT } \\
\text { multimedia systems }\end{array}$ & 48 & 40.7 & 31 & 26.3 & 1 & 0.8 & 28 & 23.7 & 10 & 8.5 \\
\hline $\begin{array}{l}\text { Availability of IT data base } \\
\text { system }\end{array}$ & 38 & 32.2 & 32 & 27.1 & 13 & 11 & 26 & 22 & 9 & 7.6 \\
\hline $\begin{array}{l}\text { Availability of IT } \\
\text { documents systems }\end{array}$ & 45 & 38.1 & 18 & 15.3 & 29 & 24.6 & 14 & 11.9 & 12 & 10.2 \\
\hline $\begin{array}{l}\text { Availability of electronic } \\
\text { mail and/or fax servers }\end{array}$ & 55 & 46.6 & 18 & 15.3 & 12 & 10.2 & 22 & 18.6 & 11 & 9.3 \\
\hline $\begin{array}{l}\text { Availability of University IT } \\
\text { network }\end{array}$ & 48 & 40.7 & 39 & 33.1 & 18 & 15.3 & 12 & 10.2 & 1 & 0.8 \\
\hline $\begin{array}{l}\text { Availability of IT access } \\
\text { tools }\end{array}$ & 37 & 31.4 & 41 & 34.7 & 13 & 11 & 22 & 18.6 & 5 & 4.2 \\
\hline
\end{tabular}




\section{Results of Dependent Variable- Improvement of HR Function}

The respondents were asked to give their answers to five likert scale closed ended questions in a scale of 1-5 where 1- Strongly Disagree, 2-Disagree, 3- Not Sure, 4- Agree, 5Strongly Disagree on questions related to improvement of $\mathrm{HR}$ function due to Information Technology adoption.

Table 3.5: Improvement of HR Function Due to IT Adoption

\begin{tabular}{|c|c|c|c|c|c|c|c|c|c|c|}
\hline \multirow{2}{*}{$\begin{array}{l}\text { ITEM } \\
\text { Adoption of IT in HR } \\
\text { function has lead to; }\end{array}$} & \multicolumn{2}{|l|}{ SD } & \multicolumn{2}{|l|}{ D } & \multicolumn{2}{|l|}{ NS } & \multicolumn{2}{|l|}{$\mathbf{A}$} & \multicolumn{2}{|l|}{$\mathbf{S A}$} \\
\hline & Freq & $\%$ & Freq & $\%$ & Freq & $\%$ & Freq & $\%$ & Freq & $\%$ \\
\hline $\begin{array}{l}\text { 1.reduction of running HR } \\
\text { function costs }\end{array}$ & 45 & 38.1 & 49 & 41.5 & 20 & 16.9 & 3 & 2.5 & 1 & 0.8 \\
\hline $\begin{array}{l}\text { 2.increased HR function } \\
\text { effectiveness }\end{array}$ & 53 & 44.9 & 31 & 26.3 & 24 & 20.3 & 7 & 5.9 & 3 & 2.5 \\
\hline $\begin{array}{l}\text { 3.streamlining of } \mathrm{HR} \\
\text { activities }\end{array}$ & 62 & 52.5 & 39 & 23.1 & 1 & 0.8 & 16 & 13.6 & 0 & 0 \\
\hline $\begin{array}{l}\text { 4.labour and time-saving } \\
\text { in the HR department }\end{array}$ & 56 & 47.5 & 38 & 32.2 & 13 & 11.0 & 7 & 5.9 & 4 & 3.4 \\
\hline 5.improvement of quality & 50 & 42.4 & 32 & 27.1 & 25 & 21.2 & 10 & 8.5 & 1 & 0.8 \\
\hline $\begin{array}{l}\text { 6. rapid response leading } \\
\text { to faster decision making }\end{array}$ & 72 & 61.0 & 42 & 35.6 & 2 & 1.7 & 2 & 1.7 & 0 & 0 \\
\hline 7. easier communication & 67 & 56.8 & 22 & 18.6 & 24 & 20.3 & 3 & 2.5 & 2 & 1.7 \\
\hline $\begin{array}{l}\text { 8.global market } \\
\text { connection }\end{array}$ & 43 & 36.4 & 56 & 47.5 & 9 & 7.6 & 8 & 6.8 & 2 & 1.7 \\
\hline $\begin{array}{l}\text { 9.improved knowledge } \\
\text { base of HR employees }\end{array}$ & 68 & 57.6 & 37 & 31.4 & 6 & 5.1 & 6 & 5.1 & 1 & 0.8 \\
\hline $\begin{array}{l}\text { 10. easy connectivity of } \\
\text { HR department with } \\
\text { other departments }\end{array}$ & 45 & 38.1 & 41 & 34.7 & 25 & 21.2 & 5 & 4.2 & 2 & 1.7 \\
\hline
\end{tabular}

The second section part one was aimed at finding out whether there was a significant correlation and direction of the relationship between the independent variables that is IT policy framework, IT implementation Procedure, IT literacy and IT infrastructure on adoption of IT for improving HR function in Kenyan public universities. Since the variables in this study are ordinal in nature spearman's rank-order correlation, often known as Spearman's rho was used to test the following hypothesis.

Table 3.6: Spearman's Computation

\begin{tabular}{|lcc|}
\hline Variable & Correlation Coefficient $(\boldsymbol{\rho})$ & P-Value \\
\hline IT Policy Framework & 0.526 & 0.00 \\
\hline $\begin{array}{l}\text { IT Implementation } \\
\text { Procedure }\end{array}$ & 0.535 & 0.00 \\
\hline IT Literacy & 0.490 & 0.00 \\
\hline IT Infrastructure & 0.529 & 0.00 \\
\hline
\end{tabular}


Based on the results above, the correlation coefficient $(\rho)$ between HR Function and IT policy framework was found to be 0.526 . This means that according to the study there was a strong positive correlation between the two variables (IT policy framework and HR function) which imply that an improvement in the IT policy framework would lead to an improvement of HR Function. Further, the above relationship was found to be significant at 0.05 level of significance $(\rho=0.526$ and $p$-value $=0.000)$ and therefore we reject the null hypothesis that there is no significant correlation between IT Policy framework and adoption of IT for improving HR function in Kenyan public universities.

Based on the results above, the correlation coefficient $(\rho)$ between HR Function and IT Implementation procedure was found to be 0.535 . This means that according to the study there was a strong positive correlation between the two variables which implies that an improvement in the IT implementation procedure would lead to an improvement of HR Function. Further, the above relationship was found to be significant at 0.05 level of significance $(\rho=0.535$ and $p$-value $=0.000)$ and thus we reject the null hypothesis there is no significant correlation between IT implementation procedures and adoption of IT for improving Human Resource Function in Kenyan public universities.

Based on the results above, the correlation coefficient $(\rho)$ between HR Function and IT Literacy was found to be 0.490 . This means that according to the study there was a moderate positive correlation between the two variables which implies that an improvement in the IT literacy would lead to an improvement of HR Function. Further, the above relationship was found to be significant at 0.05 level of significance $(\rho=0.490$ and $p$-value $=0.000)$. the conclusion therefore is we reject the null hypothesis that there is no significant correlation between Information Technology literacy of HR employees and adoption of IT for improving HR function in Kenyan public universities.

Based on the results above, the correlation coefficient $(\rho)$ between HR Function and IT Infrastructure was found to be 0.529 . This means that according to the study there was a strong positive correlation between the two variables which implies that an improvement in the IT infrastructure would lead to an improvement of HR Function. Further, the above relationship was found to be significant at 0.05 level of significance $(\rho=0.529$ and $p$-value $=0.000)$ thus we reject the null hypothesis that There is no significant correlation between availability of Information Technology Infrastructure and adoption of IT for improving HR function in Kenyan public universities.

\section{Logistic Regression Findings}

Ordinal logistic regression analysis which is a statistical technique that models the relationship between a criterion or dependent variable $(\mathrm{Y})$ and a set of predictor or independent variables (Xi) (for $\mathrm{i}=1,2,3,4$ ) was used. The general framework for this study was the application of the standard logistic regression model to study the variability of the Human Resource Function, which was the dependent variable (Y), by employing the factors scores as the independent or predictor variables. The table below presents the results of the logistic regression model. 
Table 3.7: Results of Logistic Regression Model

\begin{tabular}{|c|c|c|c|c|c|c|}
\hline & & B & SE $(\boldsymbol{\beta})$ & P-Value & $\exp (\beta)$ & \\
\hline IT Pol & & 0.17 & 0.03 & 0.00 & 1.2 & \\
\hline IT ImI & ure & 0.13 & 0.12 & 0.29 & 1.1 & \\
\hline IT Lite & & 0.23 & 0.11 & 0.03 & 1.2 & \\
\hline IT Inf I & & 0.22 & 0.11 & 0.04 & 1.2 & \\
\hline Note: & & & & & & \\
\hline Model & Ch & & Degree of F & dom & $\mathrm{p}$-value & \\
\hline Interc & & & & & & \\
\hline Final & & 63.33 & & 4 & & .000 \\
\hline
\end{tabular}

Based on Table 4.7, the estimated logistic regression model will be represented as below:

$\hat{\mathrm{Y}}=\exp \left(0.17(0.03) \mathrm{X}_{1}+0.13(0.12)\right.$

$\mathrm{X}_{2}+0.23(0.11) \mathrm{X}_{3}-0.22(0.11) \mathrm{X}_{4}$

According to the above results, a unit increase in the IT Policy would lead to an increase in the Human Resource Function by 1.2 units. However, this association was found to be significant at 5\% level of significance $(p=0.00)$. In addition, a unit increase in the scores of IT Implementation Procedure would lead to an increase in Human Resource Function by 1.1 units when all the other variables are held constant. This association was found to be insignificant at $5 \%$ level of significance ( $\mathrm{p}=0.29)$. The results of the study showed that a unit increase in the IT Literacy would lead to an increase in the Human Resource function by 1.2 units when all the other variables are held constant. This relationship was found to be significant at 0.05 level of significance $(p=0.03)$. On the other side, the study established that a unit increase in the scores of the IT Infrastructure would increase the Human Resource Function by 1.2 when all the other variables are held constant. Moreover, this relationship was found to be significant at $5 \%$ level of significance $(\mathrm{p}=0.04)$.

\section{Recommendations}

1. There is need to make sure that the involvement of all stakeholders in IT Policy formulation to promote awareness among them.

2. Need to have a well planned and organized procedure of implementing IT in Human Resource Function.

3. There is need for management to undertake an audit and prepare an inventory of IT Literacy skills among HR Function employees. In addition to that there is need for management to facilitate and support IT training among employees working in the HR function.

4. There is need to invest in IT Infrastructure within the HR Function to boost the adoption of information Technology.

\section{Conclusions}

The major findings of the study were that all independent variables (IT policy, IT implementation procedure, IT Literacy and IT infrastructure) were determinants in adoption of IT for Improving Human Resource Function in Kenyan Public Universities. Thus correlation coefficient results and ordinal regression findings support the conclusion that independent 
variables are positively and significantly related to adoption of IT for improving the HR function.

From the study findings we can conclude generally that without IT Policy Framework, IT Implementation Procedure, IT Literacy and IT Infrastructure we cannot expect improvement of HR Function due to IT adoption. Specifically, on objective one it can therefore be concluded that the existence of an IT policy does not automatically translate into every employee knowing of its existence and what it contains. Second objective the implementation procedure according to the HR Function employees is poorly planned and organized. Third, regarding IT literacy the employees have taken self initiative to acquire IT literacy skills despite lack of support from the management.

In the current study the researcher aimed at finding out whether IT Policy Framework, IT Implementation Procedure, IT Literacy and IT Infrastructure are the facilitating conditions for technology behavior use. This was developed from the Unified Theory of Acceptance and Use of Technology (UTAUT) which mentions facilitating conditions as factors for technology behavior use but doesn't specifically name them. This study develops the theory further by naming IT Policy Framework, IT Implementation Procedure, IT Literacy and IT Infrastructure as facilitating conditions for technology use behavior.

\section{References}

Ayoo, P. \& Otike, J. (2002). "Factors Hampering the Formulation of a National Information Policy in Kenya," Library Review journal, 51(7), 350-357.

Boudrean, J. (1995). 'Growing Role for Managing Human Resources,' SAGE Publications Ltd, London.

Dunivan, L. (1991). 'Implementing a UserDriven Human Resource Information System,' Journal of Systems Management, 42(10), 13-15.
Easterby-Smith, M., Thorpe, R. \& Jackson, R. (2008). 'Management Research,' Sage Publications Ltd, London.

Field, A. (2009). Discovering Statistics Using SPSS, SAGE Publications Ltd, London.

Gravetter, F. J. \& Forzano, L. A. B. (2009). 'Research Methods for the Behavioural Sciences,' (3rd ed.) Belmont, CA: Wadsworth.

Kandiri, J. M. (2006). 'ICT Policy in Kenya and Ways of Improving the Existing Policy,' University of Nairobi Publication, Nairobi.

Kumar, R. (2005). Research Methodology- A Step-By-Step Guide for Beginners, $S A G E$ Publications Ltd, London.

Oz, E. (2009). 'Management Information Systems,' (5th ed), Course Technology Cengage Learning, U.S.A.

Pfeffer, T. (2003). "Virtualization of Research Universities: Raising the Right Questions to Address Key Functions of the Institution," Centre for Studies in Higher Education, Research and Occasional Paper Series, CSHE.6.03: 1-22.

Poghisio, S. (2008). 'About Kenya ICT Board,' [Online], Minister of Information \& Communications. [Retrieved September 5,2012], http://www.ict.go.ke/inner.php?cat=abtus.

Scott, J. T., Rundall, T. G., Vogt, T. M. \& Hsu, J. (2006). "Kaiser Permanente's Experience of Implementing an Electronic Medical Record: A Qualitative Study," British Medical Journal, 331(3), 1313-1316.

Teo, T. S. H., Soon, L. G. \& Fedric, S. A. (2001). "Adoption and Impact of Human Resource Information Systems (HRIS)," Research and Practice in Human Resource Management Journal, 9(1), 101-117.

Venkatesh, V., Morris, M. G., Davis, G. B. \& Davis, F. D. (2003). "User Acceptance of Information Technology: Toward a Unified View," MIS Quarterly, 27(3), 425-478. 